\title{
The Model for Establishing Competitive Advantage of Retail Chains for Countries in Transition
}

\author{
Mila Kavalići, ", Marko Vlahović ${ }^{1}$, Dejan Đorđević ${ }^{1}$, Dragan Ćoćkalo ${ }^{1}$, Sanja Stanisavljev $^{1}$ \\ ${ }^{1}$ University of Novi Sad, Technical faculty "Mihajlo Pupin”, 23000 Zrenjanin, Đure Đakovića bb, \\ Republic of Serbia
}

\begin{abstract}
This paper presents a formulated model for the establishment of competitive advantage in the field of consumer goods retail chains in the Republic of Serbia. We have also analyzed the competitive ability of the retail shops through the presentation of the model. The model starts from the analysis of customer requirements (more quality service, more affordable prices, availability of shops, purchasing pace, Internet shops), then it is focused on the process of organizational management which is under the influence of the two groups of factors - decisive factors (competitors power, marketing activities of competitors, business expenses, the margin level, the policy of assortment of commercial enterprise, productivity) and directing factors (economic policy, economic crisis, commercial policy in Serbia). As output strategies, marketing strategies for improving competitiveness of commercial organizations on the Serbian market are defined. They are oriented towards fulfilling customer requirements. The focus of these strategies is on integration, $\mathrm{Pl}$ - brand name, PR communication, CSR (Corporate social responsibility), as ways to improve competitive ability of retail chains through consumer satisfaction.
\end{abstract}

Keywords: competitiveness, retailers, requirements of consumers, marketing strategies, the Serbian market. 


\section{Introduction}

The competitiveness is considered as a system in which all economic and legal entities perform with their commercial initiative, so an economic competition is appearing among them. One of the best experts on this issue, a Nobel Prize winner George Stigler, claimed that competitiveness is rivalry between the competitors, in other words, a pressure that every participant puts up with on the market. As the economic system of all countries became more complex through the centuries, and the markets became larger and overcrowded with participants competing on them, so the methods used by the companies to ensure their competitiveness on the market became more complex.

At the same time, the number of factors that were conditioning the competitiveness was increasing, with some of them such us: supply-side factors, demand-side factors and factors that are causing joining or rejection of the supply and demand. Jugović, T.et all. Fju (2015) emphasizes that observing the market trends which are reflected in the process of galloping globalization, tough competition, and uncertainty and in managing risks that companies are facing with, the application of the concept of managing relations with the customers should represent a starting point in creating business strategy.

Different forms of promotional activities can be divided into two groups: activities used for promotion of products (primarily advertising and sales promotion) and activities used for promotion of rulers (advertising and public relations). The need to promote the products emerged with the development of trade and the occurrence of a large number of competitors. It was necessary to convince the people that the product of a particular trader or craftsman was better than the product of their competitors (Starčević S., 2015., p.92.). In the decades, behind us, the power in the chain of value moved from the manufacturer towards retailers. Following these events, many important changes have happened in managing the companies participating in the consumer goods industry. In the last decade there has been a displacement of power from retailers to the customers (Veselić D., \& Golijanin D., 2015., p. 301.).

The satisfaction of customers, accomplished by quality business cooperation, represents a base for ensuring their loyalty, business modernity and notable presence on the market. A special issue for developing and applying the concept of customer relationship management in domestic companies are inadequate business orientation, organizational culture and management's aversion to innovations. In fact, the lack of market orientation and awareness of the management that permanent competitive advantage, productivity and innovation can be ensured only by applying the concept of customer relationship management is a critical factor that significantly decreases business results (Jugović, T., et al. 2015., p. 285-296.).

\section{Theoretical research}

\subsection{Competitiveness of retail chains}

Trends and development of the retail sector in Central and Eastern Europe have dramatically changed in the last two decades. These markets serve about 63 million of the population and there are more and more model examples for a successful transformation of the developing market. Retail market in this part of Europe is generally consolidated, so the retail chains from Western Europe have a supremacy. International retail chains are using all forms of modern distribution, with special attention to the development of hypermarkets, supermarkets and 


\section{iERPMF}

discount stores. Big competition on this market contributed to the decrease of inflation rate because of the so-called Wall Mart effect. That is why a strong retail marketing has developed nowadays in these countries, which aims to have an influence on the customer and suggest him which store is the best choice for shopping (Machek, M., 2012).

The leading role of retail in food marketing channels gives a significant contribution to the affirmation of purchase marketing - new marketing paradigms which focus on the customer and the place of sale. An important research result is that the customers' perception on the food retail market demands a profiled approach to the adjustment of retail store strategy, which includes programs and purchase marketing activities (Bogetić Z., et al., 2016). This can be best observed in the case of autochthonous food products. According to Puškarić A., (2016) the development of rural areas is stimulated by the production and sale of autochthonous food products, along with the preservation of national identity and there enriches the region's supply. Autochthonous food products, besides the sociological have also the economic significance, which reflects in competitiveness, profitability of manufacturers, which perceive the performance from consumers' satisfaction point of view. The specific associations (traditional, domestic, natural, etc.) can create an added value while placing at the domestic market. Based on added value, these products achieve a higher price on the market, while consumers are satisfied with their consumption. Higher production and supply increase the competitiveness, which have a positive effect on the increase of quality (Puškarić A. at al., 2016., p. 91.).

Serbian companies have been uncompetitive on the international market for quite a long time. Low productivity and insufficient investing in achieving business quality represent the main reasons for the poor competitiveness of domestic companies. Insufficient competitive ability became obvious after the occurrence of the world economic crisis. (Đordević et al., 2013). The need for state intervention increases with the global crisis phenomenon. However, the intervention should be in favor of the market, in other words, in favor of maintaining the market competition and not introducing of the state economy(Lovreta S., et al., 2009). Dealing with the flow and exchange of information, are the main conditions for the successful business of chains for supplying and satisfying all participants (Tomašević M., et al., 2016).

Purchase marketing is a recent, but promising business initiative. The distinction in comparison with the traditional marketing paves the field of new connections, partnerships and better results of retailers and suppliers. Retail is identified as a gravitational focus of cooperation between the companies and a new business consensus (Bogetic Z., et al., 2016). Interconnection of the companies is extremely important for their successful individual and mutual activity. The supply chain among business partners is one of the most powerful ways of accomplishing and maintaining competitive advantage on the modern market, where things are changing fast and unpredictably. Such events on the market are causing some companies to connect through appropriate supply chains, because their individual survival on the market would be unpredictable, despite the inventive and proactive abilities (Frederick D., 2004.).

Therefore, competition nowadays does not rule among the organizations, because its focus has moved on the supply chains ( $\operatorname{Lin}, \mathrm{C}$. et al., 2002).Despite the fact that some companies are facing global competition and are exposed to constant and fast customer demands, they are also facing technological changes that influence the decrease of the adjustment time, regarding the competition on the market (Overby E., et al., 2006), (Ganguly A., et al., 2009) (Sambamurthy $V$., et al., 2003). Modern and marketing directed trade represents a real leader of economic development. Trade reflects economy because all commercial and total transitional problems 
are breaking through it. That is why the management of distribution channels is one of the most important tasks of trade development. The main goal in shaping the distribution channels is to find the most efficient combination for a certain product-market-channel which minimizes distribution costs while reaching out to final consumers. The choice of distribution channels is made only after consideration of the market, products, manufacturers, mediators, competition and the environment (Lovreta S, 2003).

The world financial crisis, which started in 2008 and was immediately transferred to Serbia, caused the trend of growth in market share, when it comes to small stores. According to numerous surveys carried out for this reason, it has been confirmed that the majority of customers, regarding the big crisis, is ,afraid "to shop in large stores, because in that way they almost always spend more money than they have planned. Instead, the consumers chose to spend less money on food and to shop in stores that are nearest to them. From that moment, the development of the Serbian retail market, which is in the state of consolidation and is moving towards the goal to evolve from dominantly traditional to the organized retail market of consumer goods, has stopped. In order to accomplish that, it is necessary that largest retail chains in Serbia have a total market share bigger than 50\%, and preferably even up to $75 \%$, as it is the case in the developed western countries (Vlahović M. et al., 2016, p.38.).

The commerce in Serbia, as in other transitional countries, is characterized by incoming of foreign trade companies, opening new firms through a franchising system, building large retail forms (hypermarkets, supermarkets, Cash \& Carry systems), etc. (Bennison \& Boutsouki, 1995). Therefore, the transition process has had a largest influence on the change in retail structure over the last few years (Radosavljević \& Borisavljević, 2014).

\subsection{Consumers' behavior}

Due to the strong process of economic and social globalization, the competition between the organizations is getting more intense, while the offer of goods and services is becoming richer. On the other hand, the consumers and users of products and services, are becoming more demanding. Their sophistication and fussiness have a real base in the increasing level of their education and awareness, but also in a significantly higher offer in comparison to the demand, or in other words, in wider range of products and services offered by the organizations, in attempt to differentiate their offer from the competition, in order to „bind“ the consumers to themselves, as well as to their products and services. (Salai, \& KovačŽnideršić, 2012).

On the retail market the consumer is put in the center of events and represents the main source of information necessary for the market improvement. Most special rules of the EU, which predict the additional protection of the weaker party in the mass sale of products and standardized services, mark this party under the term „consumer“ and define it as a „physical person who comes forward for the purposes beyond its commercial, business, vocational or professional activity “(Directive on consumers' rights, 2011, art. 2, pg.1, art. 1).

The policy of consumer protection represents one of the most important issues in the European Union. Despite the significant efforts towards harmonization, there are still present different positions of the consumer protection development in certain countries of the EU. The Republic of Serbia, on its path of Euro integration, apart from other tasks, in the past several years works intensively on fixing the position of consumers and on implementing directives and guidelines of the European Union in this field. 


\section{iE跑MF}

The important reasons for the state authorities to dedicate to the issue of consumer protection are: common occurrence of market anomalies, unethical behavior of the companies, lower quality of goods and services, but also the pressure of the consumers and their organizations. Passing of the appropriate law, adoption and implementation of integrated consumer protection strategy in the Republic of Serbia, as well as operation of consumer organizations, have given certain results (Veljković, S. 2013. p. 47.). With all respect to some similarities in product and service placement on the final and business market, the aims and motives for purchase are still significantly different (Veljković, 2009, p. 81).

Customers and consumers on the final market are purchasing the products and services of lower value, for themselves or for the family, and they often react emotionally when they are shopping. On the other hand, business customers usually act as a team and much more analytically, without emotions and they are taking maximum care of the acquisition costs optimization, but also of establishing, building and fostering good long-term business relations, especially with their suppliers, but also with all the other actors from the environment, in order to ensure efficient communication, continued and profitable management of their organization. (Jovičić, \& Salai, 2011, p. 155).

\subsection{How customers choose the store where they shop}

The customers choose stores considering five dimensions and making priorities among them: 1. access, 2. atmosphere in the store, 3. prices and promotions, 4. combined category of product and service assortment, and 5. assortment within the category of brands and/or products. The store's location and its distance are the main criteria for the consumer when choosing the store. Starting from the gravitation model (Huff, 1966), the choice of the store and optimization of the sales location have attracted a lot of attention in researches carried out during the '80. (Achabal et al., 1982; Donthu \& Rust, 1989; Ghosh \& Craig, 1983).

According to Vlahović M. average Serbian customer usually goes to a nearby shop. The strongest impact on the market share of retail chain stores of consumer goods has the size of the retail network, and therefore there is a strong dominance of traditional trade in comparison to organized one (Vlahović at al. 2016.,pp.43-44), (GFK).Apart from this factor, which we consider to be dominant, there is also a factor of generally good prices. Considering this indicator precisely, it is clear that in 2014/2015 there was a significant rise in the number of those who find this factor crucial for choosing the store, but it is important to mention that this factor yet remained at the same level as in 2012/2013, when it comes to category of the „main reason" (Vlahović at al. 2016., p.43-44), (GFK).

As we can see, nearness is the strongest factor for choosing the store, so it would also be useful to know if the customers stay loyal to the stores where they shop. The research Shopping monitor, carried out by the agency GFK, indicated that more than 50\% (57\%) of customers claim that they always shop at the same store, $24 \%$ shop at two or three different stores, $13 \%$ said that they do their shopping in various stores, while $6 \%$ of examinees combine different stores, but stay loyal to them, too. What is particularly interesting is that this indicator increased by 6\% during 2014/2015. (GFK Potrošački monitor 2014/2015).

\subsection{The factors of competitive advantage}

According to Stankovic at all (2014), the competitiveness factors are classified into 12 groups, the so-called pillars of competitiveness, which reflect various aspects of complex 
economic reality. Afterwards, the pillars of competitiveness are classified in three groups: 1) basic factors (institutions, infrastructure, macroeconomic stability, health care and primary education), 2) factors that have an influence on improving efficiency (higher education and specialization, goods market and labor market efficiency, development level of the financial market, technological competence, market size), and 3) factors that refer to innovations(sophistication of business and innovations) (Stanković at all. 2014, p. 273).The most important factors that are missing in the development of Serbian companies' competitiveness are: new technologies (12.94\%), motivation of employees (11.41\%), education $(9.93 \%)$ and financial support $(9.21 \%)$. According to examinees, the following elements are necessary for the development of domestic companies' competitiveness: business quality standardization (17.22\%), using modern management methods and techniques (17.08\%), investing in development of national brands (17.08\%) and purchasing new technologies (13.02\%) (Đorđević et al., 2011).

According to Tepavac D., (2014), the factors that influence the creating of brand image with consumers are quality, relationship with the consumers and promotion activities. If we observe the highest frequency of certain factors, quality stands out with over $87 \%$, while the employees in the company are the least influential factor with only $9,9 \%$. Slightly less than $20 \%$ of the people who participated in the research think that social responsibility is the key factor which has an influence on their attitudes towards a certain branded product. Based on the presented results, it can be concluded that the consumers in Serbia, despite demographic characteristics, believe that quality is the crucial feature of branded products, which at the same time, represents an inevitable characteristic in modern company business in Serbia, as well as in the whole world (Tepavac, D., \& Kostić-Stanković, M. 2014.,p.29-40).

\section{Methodology}

\subsection{Issue and the subject of research}

The issue of this research is related to finding ways for the establishment of retail chains competitive advantage. The outcome of the research represents the formulation of a model for establishing competitive advantage through the process of satisfying customer requirements in the field of retail chains of consumer goods in the Republic of Serbia. The research subjects are the companies from this field that have distinguished position on the market in regards to other competitors. The observed companies are being investigated in terms of both customer requirements and the process of organization management as well. The research subject involves the consideration of all factors which affect competitive business performance of commercial organizations.

\subsection{Research objective}

The research objective of Serbian retail market of consumer goods represents the identification of the key factors that affect the growth of market share. The focus is on the identification of all factors which contribute to commercial growth and the growth of market share through the establishment of competitive advantage of retail chains and through customer behavior observation. 


\subsection{Research methodology and organization}

We observed the market of retail consumer goods in Serbia, in other words, marketing activities of 10 biggest retail chains in the period of time from 2012 to 2016 . Based on analysis of their activities', we analyzed the factors that retail brands used in order to establish their competitive advantage on the market. Thereafter, a marketing strategy model which directly influences the satisfaction of customer requirements and improvement of competitive ability of commercial organizations was presented.

\subsection{Research questions}

Based on the analyzed theory, the following research questions were asked:

$R Q 1:$ Whatare the identified customer requirements?

$R Q 2$ :What are the factors of directing character which affect the process of commercial organization management?

$R Q 3$ :What are the decisive factors which affect the process of commercial organization management?

$R Q 4:$ What are the strategies which affect competitive advantage achievement?

$R Q 5: H o w$ to manage commercial organizations in order to achieve competitive advantage?

\section{THE MODEL FOR THE ESTABLISHMENT OF COMPETITIVE ADVANTAGE OF RETAIL CHAINS}

On the grounds of the research results the formulated model for establishing competitive advantage in the field of retail chains of consumer goods in the Republic of Serbia will be presented. The model presented in Figure 1. analyzes the way for establishing competitive ability of retail chains shops taking into consideration the certain factors.

The model starts from the analysis of customer requirements and then it focuses on the process of organization management which is under the influence of the two factor groups decisive and directing factors. The outcome is a marketing strategy for improving the competitiveness of commercial organizations on the market of the Republic of Serbia that are directed towards consumer requirements fulfillment.

Figure 1: The model for establishing competitive advantage of retail chains 


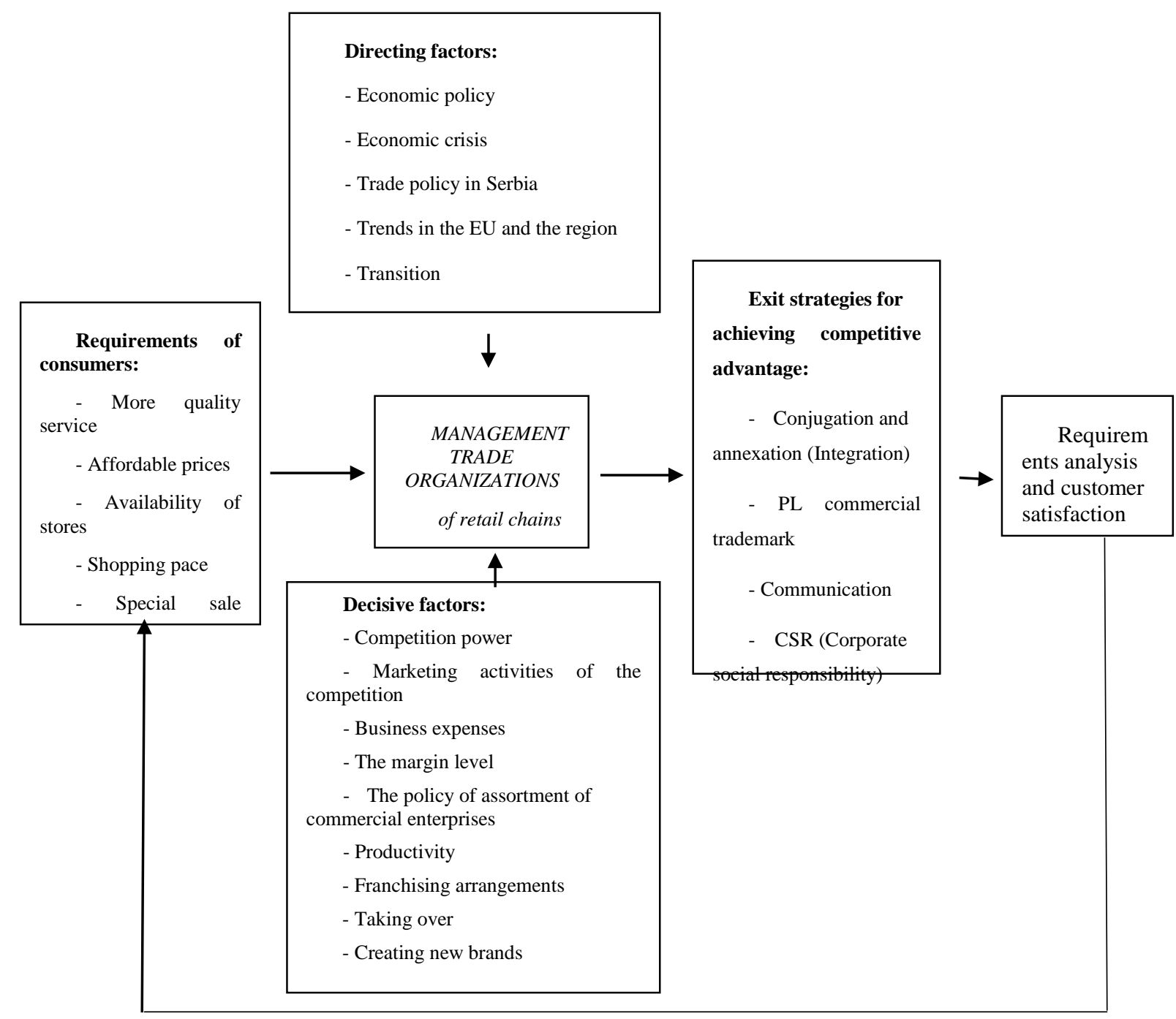

\subsection{Requirements of consumers}

\section{Requirements of consumers in this paper are as follows:}

- $\quad$ More quality service - Although the state of commerce in Serbia nowadays is not in the best of times customers still expect quality service for their money. Inspire of the stagnation in development of the commerce, the retail chains still manage to satisfy the market needs by their quality service. Quality of the service is one of the strongest factors for choosing a store.

- Affordable prices - Affordable prices are among the strongest factors in choosing the store where customers will do shopping. Retail chains in Serbia have been competing for years to improve their price perception through various actions. They have been trying to attract customers to do shopping in their stores, so the pressure on the trade mark development is rising. When it comes to prices, retail chains use two types of strategies: HiLow and EDLP (Every Day Low Prices strategies). Researches has shown that the main motivation for using EDLP pricing strategies is cutting down advertising costs and reducing labor as a consequence of cutting back on promotions, but also improving inventory management. Speaking of Hi-Low pricing strategy, it is suggested that the motivation for retailers to use this strategy is to "generate excitement, attract shoppers, clear out timesensitive merchandise and sell 
complementary, high-margin items (Voss and Seiders 2003, p. 37). EDLP strategy consists of selecting assortment that will be guaranteed as the cheapest on the market during the whole year. Even tough, this product will most likely have a negative margin during some parts of the year, they are used as a "bait" for other products with much higher price margins. On the other hand, "Hi-Low" strategies consist of setting much lower prices for products which were at the beginning expensive and with bigger margin.

- Availability of stores - For years, the strongest factor in choosing the place for shopping has been their vicinity. Customers want their stores to be available so the retail chains are permanently broadening their retail network by opening new stores and if an opportunity appears, they acquire some of the existing chains on the market.

-Shopping pace - Although shopping pace represents one of the greatest requirements, this segment has not been developed in Serbia fast enough. The main reasons are reduced investments in new technologies that can be the most powerful mean for achieving significant progress in this field. The great step forward has made the retail chains Roda and DIS by developing special services in this domain - they enabled their customers to do shopping faster than in the traditional way.

- Special sale channels -Although the Internet shops all around the world have been developed for years their development is Serbia is still modest. The first Internet variety shop was opened by Maxi and several years later Univerexport and Idea followed. Only customers in big cities can buy goods in Internet shops which confirms the statement that this segment is developing very slowly in Serbia. DIS retailer chain has opened their Internet shop with the aim to be different from other retailers but it is possible only to order goods on the Internet and then go to the store and take it because they do not have delivery service.

\subsection{The factor that have an influence on the establishment of competitive advantage}

When it comes to managing commercial organizations, we marked off the influence of two factors:

\section{Directing factors, which are consisted of the following sub-factors:}

- Economic policy - When talking about the economic policy, in the context of developing retail chains in Serbia, it is considered that the current economic policy is not an aggravating circumstance in the market growth, but it is not established to be the factor of its development either. Generally, the economic policy of Serbia, in which we are representing ourselves to the world as a country with cheap labor force, definitely cannot be encouraging for the commerce development, keeping in mind that it is dependent on citizen wages in every country.

- $\quad$ Economic crisis - In the terms of retail consumer goods, the economic crisis also had a very negative effect on the development of this economic sector. From 2008, when the world economic crisis has started, the volume of overall sales regarding retail consumer goods declined in almost all countries in the world. The reason for this is the fact that large number of consumers stopped going to big shopping malls, simply because in that way they buy many unnecessary products.

- $\quad$ Trade policy in Serbia - Starting from 2003, when Stipe Lovreta and his team made the National strategy for trade development in the Republic of Serbia, our country has followed a certain direction regarding this sector (Lovreta S.,2003). This is evidenced mostly by the fact 
that some of the biggest retail chains from the region and the whole world came to Serbia in the past ten years - Slovenian "Mercator", Croatian "Agrokor", Belgian "Delhaize" and finally, German "Lidl".

- Trends in the EU and the region - When it comes to trends in the EU and the region, the strongest one is the consolidation of retail chains. The last big integration in this field in Europe is happening right now. The Belgian company "Delhaize" and the Dutch "Ahold" agreed to merge and create a retail chain with more than 6500 stores all around the world. The process of merging should be ended until 2016. One-time costs will be 350 million euros, but after that, already in the third year of existence, 500 million euros are supposed to be saved by creating "Ahold Delhaize".

- Transition- The influence of transition on the development of retail consumer goods in Serbia is still continuing. From the moment of adopting the national strategy for retail development, Serbia pointed out that, according to the world trends, the market should be consolidated in a way that ten largest retail chains on the market should have a market share of 70-80\%. According to this parameter, obtained from the research of the GFK Agency, Serbia is still in the state of transition, because of the fact that all ten leading retail chains participate on the total Serbian market with just a little bit more than 33\% (GFK., March 2015).

\section{Decisive factors, which are consisted of the following sub-factors:}

- Competition power- Although the market is not consolidated yet, the competition power of retail consumer goods is very expressive. Because of the fact that nearness is the crucial factor for choosing a store where consumers buy, the biggest competitors are large retail chains, as well as all traditional stores all over Serbia.

- Marketing activities of the competition - Even though there are economic branches in Serbia where the competition is not particularly expressed, in case of consumer goods it is on a very high level, regarding both the manufacturers and the retail. A large number of retail chains and manufacturers brought their expert skills to Serbia which led to shaking up domestic companies in order to prepare their marketing strategies even more seriously and fight for their part of the market. Retail chains are, at the moment, fighting most efficiently, by creating programs that develop the consumers' loyalty.

- Business expenses - Globally, in recent years, the companies are turning to the reduction of their expenses, understanding that, in the period of world economic crisis and decreased demand, there lies bigger profit. This type of practice happened in Serbia as well, only because the number of unemployed was increased in the last few years.

- The margin level - As in almost every other branches, including retail, the market determines the margin level. From the beginning of the world economic crisis, the margins in Serbia have been on such a low level that there is hardly any space for further reduction. Because of that, the manufacturers decided to reduce their packages, so the price would not be adjusted, while retail chains chose to lower the margin even more by constant discounts, hoping that the distinction in the sale would compensate that reduction and make the discount payable.

- The policy of assortment of commercial enterprises-A merchant plans the assortment in order to create an appropriate range and volume of the product, which he will offer to his target consumers. As an appropriate range, it is considered the one that would satisfy the consumers' needs better than competition, while making the largest sustainable profit. The level 
of assortment overlapping between retail stores in a specific market area is important to the merchant because it is, among other things, a relative factor subject to constant changes, because of its own and competitive activities as well. The more the consumers perceive the stores to have similar assortment (bigger overlap), the more they tend to equally divide their shopping between competitive stores. Actually, they do not care where they shop.

- Productivity-The labor productivity, as a fundamental economic principle, is the expression of employees' labor efficiency. In commerce, a special attention is paid to analyzing labor productivity. Considering that ten biggest retail chains cannot move from the market share of $33 \%$ for several years now, it is obvious they do not have a mechanism for increasing the traffic per employee, regarding the market battle. If a certain retail store has a problem with productivity in the case of traffic stagnation, the only way to increase its productivity is to decrease the number of employees and try to keep the same level of service and the turnover.

- Franchising arrangements-When talking about franchising in the retail of consumer goods, it is important to mention that there were several attempts in order to make a successful domestic franchise, but none of them had a significant effect, at least until now. Today, the retail chains DIS and Metro have commercial franchises across entire Serbia and both companies also have hundreds of franchise partners.

- Taking over - Taking over is a strategy used in the whole world, including Serbia, which enabled many companies to accomplish a significant market rise "in only one day". Before taking over Pekabeta and C Market, the retail chain Maxi was a small discount chain which after that became a market leader in the retail area. The retail chain Mercator, after coming to Serbia, managed to open only a few stores, but with the takeover of Rodic retail chain, it jumped to the second position on the market. Finally, the retail chain IDEA was on the fourth position on the market before its integration with Mercator, and now it broke out in the first position regarding almost every market parameter.

- Creating new brands - Creating new brands in the retail sector is quite rare nowadays. Most commonly, a world-famous franchise is taken over, or some of the foreign retail chains, like e.g. Delhaize, which decides to enter the Serbian market. Despite all of this, as one of the latest brands in the retail sector, appeared the retail chain Aroma, which is still a small chain of exclusive stores with a very pleasant atmosphere, situated in the inner center of Belgrade.

\subsection{Exit strategies for achieving competitive advantage}

Based on the analyzed requirements of consumers and the factors that influence them, the following strategies derived in order to achieve competitive advantage and business perfection along with satisfying the consumers' wishes and requirements:

- Conjugation and annexation (Integration)- One of the most efficient exit strategies for surviving on the market is synergy of the companies. A large number of retail chains in the world, and also in Serbia in the recent years, entered the process of conjugation and annexation in order to have a stronger performance on the market and to reduce mutual business expenses.

- PL commercial trademark - The development of the commercial trademark (PL) is one of the strongest exit strategies to avoid the market stagnation, precisely because of the market pressure on achieving even lower prices. Many retail chains noticed that and almost all of them, before Lidl arrived on our market, started campaigns for promoting commercial trademark products, as one of the strongest tools for differentiation on the market. 
- Communication- Marketing and PR communication are becoming more powerful in the recent years. In the periods of great savings in advertising, the imperative of every company is to be different when it comes to communication. Although they all have almost identical time provided for advertising, there are always those who use communication in a better way.

- CSR (Corporate social responsibility)-Corporate social responsibility of the companies is important even nowadays, but it will certainly become more relevant in the future. When most companies in Serbia realize that socially responsible activities do not represent an expense, but a wise investment, then this activity will become one of the crucial factors of market differentiation and strong exit strategies.

- Loyalty programs-One of the most efficient exit strategies for survival on the market are also the loyalty programs. Creating such programs became a trend in the whole world almost ten years ago, while in our country it has been present only since recently. Loyalty programs such as Super Card of the company Mercator-S, Piggy Bank of the retail chain Gomex or the Smile Card given by EKO petrol stations represent the best way for the customers to gain additional profit with every purchase, while the company receives data from which it can find out about its customers' habits.

\section{Conclusion}

On the grounds of all aforementioned it is possible to conclude that customer requirements, described in the model, are perhaps the strongest factor in positioning on the market. The model is focused on consumer requirements and on the process of organization management under the influence of the two groups of factors - decisive and directing factors. Marketing strategies for improving competitiveness of commercial organizations on the Serbian market are defined as output strategies and they are oriented towards consumer requirements fulfillment.

These output strategies are focused on the ways of improving competitive ability of retail chains through consumer satisfaction. On the grounds of the observed situation on the market, the strategies are created with the aim to affect consumer satisfaction. When speaking about the analysis of the requirements and consumer satisfaction, regarding the aforementioned and the experiences coming from studying this field, we can conclude that the consumers in Serbia are generally satisfied by the development of the trade mark products which resulted in a powerful stoppage of the rise of the most developed world brands prices.

However, considering consumer requirements which are not on the level of some developed countries yet, we can say that there is room for development and improvement especially in regards to quality and more affordable access to shops. The presented model could serve as an example of good practice and the retail chains can use it to improve their competitiveness on the market. 


\section{References}

[1] Achabal, D., Gorr, W., \& Mahajan, V. (1982). MULTILOC: A multiple store location decision model. Journal of Retailing, 58, p.5-25.

[2] Bennison, D., \& Boutsouki, C. (1995). Greek Retailing in Transition. International Journal of Retail \& Distribution Management, 23(1), p.24-31, doi: 10.1108/09590559510078098

[3] Bogetić, Z., Kaličanin, Đ., \& Stojković, D. (2016). Shopper marketing: A new partnership perspective in marketing channels. Ekonomski horizonti, 18(1), pp.53-69., doi:10.5937/ekonhor1601053B

[4] Directive on Consumers' Rights (2011), art. 2, pg.1, art. 1doi: 10.5937/ekonomika1604085P

[5] Đorđević, D., Ćoćkalo, D., \& Đurin, S. (2011). Serbian enterprises and global competition challenges. Journal of Engineering Management and Competitiveness (JEMC), 1(1/2), p.27-31.

[6] Đorđević, D., Sajfert, D., \& Gligorović, B. (2013.). Quality management concept and competitiveness of Serbian companies. Journal Of Engineering Management and Competitiveness (JEMC), 3(2), p.79-84.

[7] Ganguly, A., Nilchiani, R., \& Farr, J. V. (2009). Evaluating agility in corporate enterprises, International Journal of Production Economics, 118(2), p.410-423, doi: 10.1016/j.ijpe.2008.12.009

[8] GFK. (2015). Internal date "Diary of Panel household"Shopping monitor 2014/2015. Belgrade: GFK. - Viewed 07.04.2016. 
[9] GFK. (2015). Internal date "The structure of personal consumption by current prices" Shopping monitor 2014/2015. Belgrade: GFK. - Viewed 07.04.2016.

[10] GFK. (March 2015). Internal date "Loyalty when large shopping"Retail monitor 2014/2015. Belgrade: GFK. - Viewed 07.04.2016.

[11] GFK. (March 2015). Internal date "Reasons for choosing main retailers" Retail monitor 2014/2015. Belgrade: GFK. - Viewed 07.04.2016.

[12] GFK. (March 2015). Internal date"The participation in value of retail formats" Retail monitor 2014/2015. Belgrade: GFK. - Viewed 07.04.2016.

[13] Huff, D. L. (1966). A programmed solution for approximating an optimum retail location. Land Economics, 42(9), p.293-303, doi: 10.2307/3145346

[14] Jovičić, D., \& Salai, S. (2011). Poslovno komuniciranje. Novi Sad: Visoka poslovna škola strukovnih studija

[15] Jugović, T., Petrović, D., \& Kostić-Stanković, M. (2015). Upravljanje odnosima sa kupcima kao izvor konkurentnosti kompanija u promenjivom okruženju. Marketing, 46(4), p.285-296., doi:10.5937/markt1504285J

[16] Lin, C., Hung, H., Wu, J., Lin, B., A, (2002). Knowledge Management Architecture in Collaborative Supply Chain, Journal of Computer Information Systems, 42., p.83-94.

[17] Lovreta S., (2003). Strategija i politika trgovine Republike Srbije, Ekonomski fakultet Univerzitet u Beogradu

[18] Lovreta, S., Manić, E., \& Stojković, D. (2009). Model for Managing Trade Policy in Cerating Modern Market Economy. International Conference "Economic Policy and Global Recession” Belgrade: Faculty of Economics, University of Belgrade. p. 175-184.

[19] Machek, M. (2012). Retail Market Structure Development In Central Europe, Central European Review, 1(3)

[20] Mercator-S (2016). Internal date "The number of shops according to the retail brands. Beograd, Serbia. 01.04.2016.

[21] Overby, E., Bharadwaj, A., \& Sambamurthy, V. (2006) Enterprise agility and the enabling role of information technology, European Journal of Information Systems, 15(2), p.120-131, doi:10.1057/palgrave.ejis.3000600

[22] Puškarić A, Kuzman B. (2016). Impact of promotional activities on the development of autochthonous food products, Institute of Agricultural Economics, p. 62.

[23] Radosavljević, G., \& Borisavljević, K. (2014). Opšti pokazatelji stanja i razvoja trgovinske mreže u Šumadiji., p.205-219.

[24] Ross David F. (2004), Distribution: Planning and Control Managing in the Era of Supply Chain Management Second Edition, ISBN: 1-4020- 7686-X, Springer US, doi: 10.1007/978-1-4899-7578-2

[25] Salai, S., \& Kovač-Žnideršić, R. (2012). Marketing: Trends and behaviour patterns. Škola biznisa, 9(1), p.15-23. doi:10.5937/skolbiz1201015s 
[26] Sambamurthy, V., Bharadwaj, A., \& Grover, V. (2003). Shaping agility through digital options Reconceptualizing the role of information technology in contemporary firms. MIS Quarterly, 27(2), p.237-263.

[27] Stanković, Lj., Đukić, S. \& Popović, A. (2014). Marketing inovacije kao izvor konkurentske prednosti preduzeća. Marketing, Vol. 45, No. 4, p. 271281,doi:10.5937/markt1404271S

[28] Starčević S. (2015). The Origin and Historical Development of Branding and Advertising in the Old Civilizations of Africa, Asia and Europe, UDK, 46 (1), p.92.

[29] Tepavac, D., \& Kostić-Stanković, M. (2014). Značaj korporativne društvene odgovornosti u kreiranju brenda. Marketing, 45(1), pp.29-

40,doi:10.5937/markt1401029T

[30] Tomašević, M., Tešić, Z., Kuzmanović, B., Stevanov, B., \& Todić, V. (2016). Razvoj modela upravljanja lancima snabdevanja. Infoteh-Jahorina, 15(1)

[31] Vaselić D. \& Golijanin D. (2015), Shopper Marketing as a Way to Improve Competiti Vene Ss In The Western Balkans Region, Preliminary paper udk: 005.346 339.13(497-15) Date of Receipt: December 12, 2015, p.301.

[32] Veljković, S. (2009). Marketing usluga. Beograd: Centar za izdavačku delatnost Ekonomskog fakulteta u Beogradu.

[33] Veljković, S. (2013). Zaštita potrošača u Republici Srbiji u procesu pridruživanja Evropskoj Uniji. Marketing, 44(1), p.49-74.

[34] Vlahović Marko, Kavalić Mila, Borić Slađana, Stanisavljev Sanja, Curčić Nikola: „The Impact of the number of retail outlets on the market share of consumer goods' retail brands", "Journal of Engineering Management and Competitiveness" (JEMC) 2016., ISSN:22178147, COBISS.SR-ID 268908551. Vol. 6. No. 1. p. 36-45.

[35] Voss G., Seiders K. (2003), Exploring the Effect of Retail Sector and Firm Characteristics on Price Promotion Activity, Journal of Retailing, p.37-52, Sloan Management Review, doi: 10.1016/S0022-4359(03)00003-4 